\title{
Geophysical Investigation of Groundwater Regime: Case Study of Etioro-Akoko Southwestern Nigeria
}

\author{
Okpoli C. Cyril $^{1}$, Saba A. Emmanuel ${ }^{1}$, Oduneye O. Christopher $^{2}$ \\ ${ }^{1}$ Department of Geology, Adekunle Ajasin University, Akungba-Akoko, Ondo State, Nigeria \\ ${ }^{2}$ Department of Earth Sciences, Ladoke Akintola University, Ogbomoso, Oyo State, Nigeria
}

cross $^{\text {ref }}$ http://dx.doi.org/10.5755/j01.erem.69.3.5334

(Received in September, 2013; accepted in September, 2014)

The electrical resistivity study of Etioro-Akoko has become imperative because of non-functional potable water. The study aims at resolving the geology setup through hydro-geophysical methods and modeling of the wells. Dipole- dipole, Schlumberger array and the positioning of the hand dug wells were carried out in the study area.

Dipole-dipole array results in the study area do not show structures indicative of high groundwater yield potential. Three layers comprising of the topsoil, weathered layer, and the fresh basement were delineated using the Schlumberger array with overburden thicknesses ranging from 4.5-7.7m. The values are too thin to support productive wells. Well inventory (depth to well-base) results ranges from 5.3-7.3m and were used to model the direction of flow pattern of groundwater. The southernmost part of the map is continuously discharged. To tap into the groundwater resources in this area requires detailed geophysical mapping and investigations of the discharge area.

Key words: Etioro-akoko, dipole-dipole, schlumberger, modeling and groundwater

\section{Introduction}

Where would people be without water? What about the importance of water in shaping the earth? Well, aside from not being alive, we may never have evolved the big brains that made us such unique species. The average man requires 2.5 liters of water per day for direct consumption and about 200 liters for domestic purposes. (Hamill and Bell, 1986). Industries on the other hand generally require approximately one quarter to one third of the public water supply.

A very important need for all activities and processes that happen on this planet and beyond, there is no living thing that survives without water. Such is the importance of water that even the earliest civilizations started and flourished around river valleys such as the Nile in Egypt, Indus in India, Hung Ho in China, and Euphrates and Tigris in the ancient Mesopotamia.

With the growing population of human beings creating a need for new settlements, villages, towns and cities are usually sited where there is abundant availability of potable water. Since rivers as do other surface water bodies such as lakes and springs cannot be found everywhere, there is a huge need to tap into subsurface water. Otherwise known as groundwater, it constitutes 97 percent of the world's fresh water supply. However, fresh water supply is only $1 \%$ of total water available (Ayoade J. O., 1988).

With the location of Adekunle-Ajasin University in Akungba-Akoko, a town less than ten kilometers away from Etioro, the study site, there was an expected influx of people and industries into the community as well as other neighboring towns and villages. However, the population of new settlers has been very low when compared to the rate at which it increases in other towns close to the University. This is largely explained by the relatively low availability of potable water in Etioro community. Although blessed with springs and a stream which flows around and about the outskirt of the town, this water sources are more often than not polluted and contaminated when they are not dry. Etioro has donated a sizeable 
population to the estimated 2 billion people that lack adequate water supply and the 385000 children that die annually of water borne diseases in developing countries (Hamill and Bell 1986).

Several attempts to tap into groundwater in Etioro have been unsuccessful. More than three boreholes have been drilled in Etioro which cannot be described as productive as they hardly produce enough water for domestic use in the town. Even hand dug wells in Etioro are hardly productive all year round. A study conducted on more than fourteen hand dug wells in the community shows that only two wells had water more than 1.5 meters deep while others ranged from not yielding water at all to $0.25 \mathrm{~m}$ to $0.45 \mathrm{~m}$.

In order to influence the developmental rate of this town, and also decongest Akungba-Akoko of its rapidly growing population, there is a need to evaluate the zones of high yield groundwater, a problem which this research work is aimed at solving.

Ajayi and Adegoke (1998) conducted a geological investigation for groundwater exploration in the basement complex (i.e. for fairly large areas such as estates and farmlands) based on surface geological mapping. Their inferences were based on forty (40) wells that were drilled for several clients in the basement complex of southwestern Nigeria since 1981. They however recommended geological investigation only where the need is for high yielding single boreholes that will tap favorable fractures or fault zones or pegmatitic bodies.
Hazel (1992) and Aina (1996) revealed that the bedrock resistivity less than $1000 \Omega \mathrm{m}$ are incompetent and most probably fractured.

Successfully, electrical resistivity method has been used in locating sites for boreholes in the Southwestern basement complex of Nigeria. (Olorunfemi and Olorunniwo, 1985; Olayinka, 1990; Olorunfemi, 1992).

Omosuyi, Ojo and Enikanselu (2003) used electrical resistivity method to investigate ObanlaObakekere area of Akure and evaluated the groundwater potential of the area using DIPOLEDIPOLE array to generate geo-electric sections and maps.

The conclusion from observation and experience is that local geological conditions, some of which are not readily detected by Geophysical investigations play a critical role in the yield of wells located in the basement complex areas of the southwestern Nigeria. Suggestions based on field experience as to the proper roles of geology and geophysics has been made by several authors.

\section{Site location and description}

Etioro-Akoko is located along Owo-IkareAkoko road in Akoko Southwest Local Government Area of Ondo state Southwest Nigeria. It is located within latitudes $07^{\circ} 26.27$ and $7^{\circ} 26.36$ within longitudes $005^{\circ} 43.05$ and $005^{\circ} 43.35$. Etioro is less than ten kilometers away from Akungba-Akoko. (Ojo S.O., 2000).

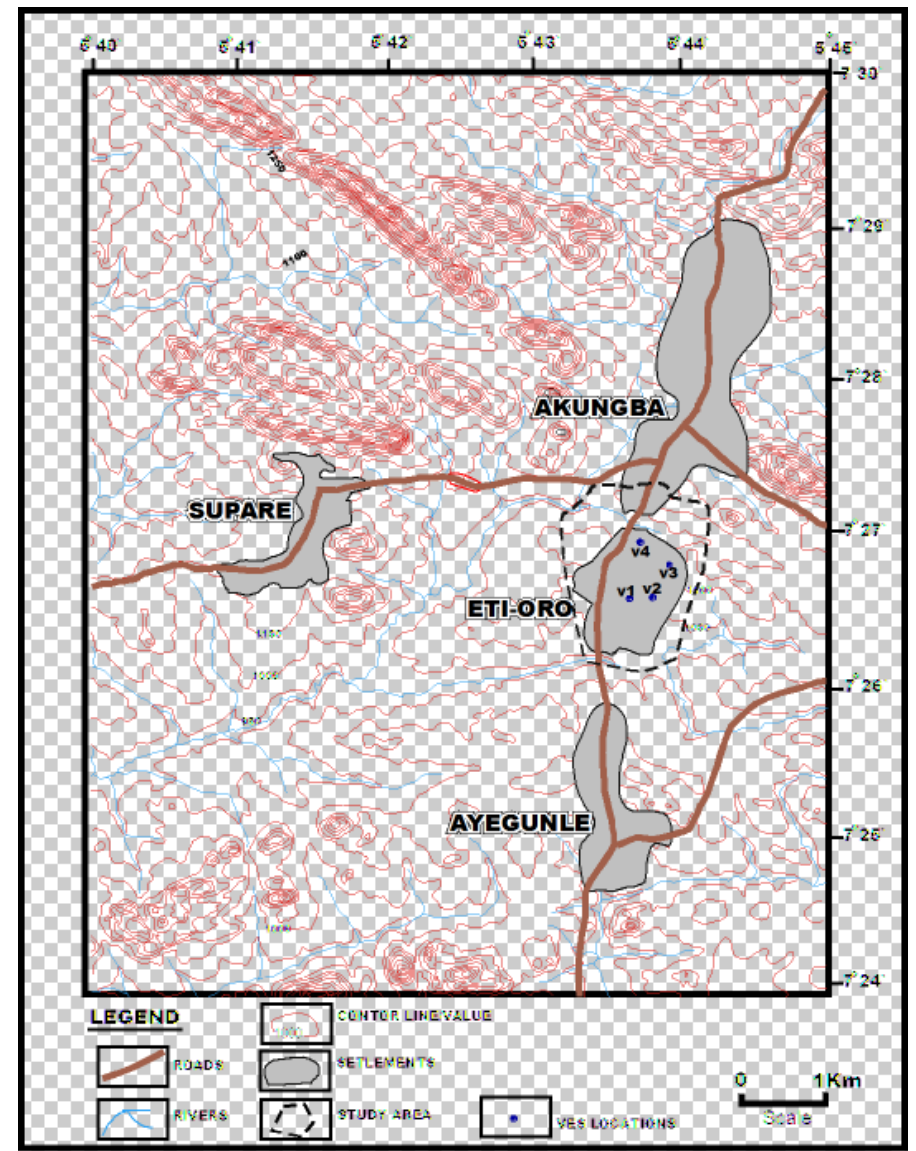

Fig. 1. Topographical map of Etioro-Akoko and its Environs showing VES locations 


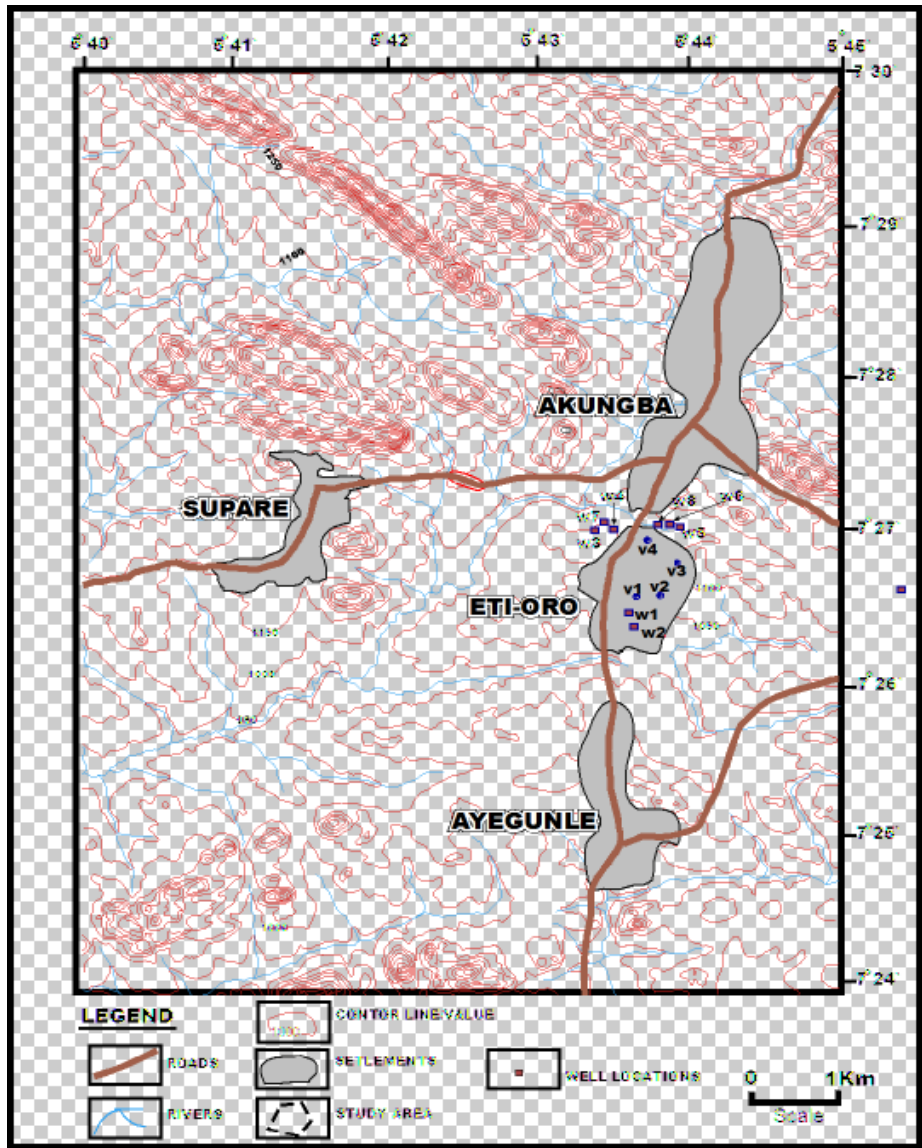

Fig. 2. Topographical map of Etioro-Akoko and its Environs showing Well locations

\subsection{Geomorphology, climate and vegetation}

Etioro community is surrounded by high elevation hills but the lowlands constitute the settlement and farm areas. There are very few rock outcrops and exposures within the settlement. Etioro has an averagely flat terrain/topography with an elevation ranging from between 1108 and $1118 \mathrm{ft}$. (Ojo S.O 2000)

This area is located in the tropical rainforest belt of Nigeria with annual rainfall just like most parts of the southwest. The climate here is dictated by the southwestern monsoon winds. Rain starts in March with peaks during July and September while the dry season starts between October and November. Etioro just like many other towns in Southwestern Nigeria is characterized by the tropical wet and dry climate. The mean annual rainfall varies between $1000 \mathrm{~mm}$ and 1500mm (Ojo S.O 2000).

The vegetation of Etioro is mainly savannah and mostly farmlands. It comprises of big trees with undergrowth under them.

Groundwater in this area is primarily recharged by precipitation of rainwater accounting for the low yield and productivity of hand-dug wells and boreholes during the dry season. The area experiences high rainfall but notwithstanding the constant annual recharge, well productivity here is low with many abandoned wells and unproductive bore-holes visible within the settlement

\section{Methods of study}

Geological/reconnaissance investigation. The lithology that dominates this area belongs to the Precambrian Basement Complex and belongs to the Quartzite-Migmatite-Gneiss complex. The major lithological unit includes the Granite gneiss and the Grey gneiss. Major fault axes are not noticeable in Etioro. However, micro-structures such as joints and fractures are obtainable in the study area.

Well inventories were taken at more than 21 hand dug wells in the study area to determine the productivity of aquifer units in the area. The study reveals a very thin layer of overburden, as most wells in this area make contact with the bedrock at relatively shallow depths ranging from as shallow as 0.2 to 7 meters.

Field procedure. We carried out Schlumberger and dipole-dipole configuration methods in this research work.

\subsection{Schlumberger configuration}

In this configuration, four electrodes are needed. The electrode spacing is derived by increasing the distance between the current electrodes while the potential electrodes remain constant, such that the distance $A B / 2$ between the electrodes is at least five times the separation between the potential electrodes MN (Figure 3.5). 
Where: $r_{1}=L-1 ; \quad r_{2}=L+1 ; \quad r_{3}=L+1 \quad$ and $r_{4}=L-1$.

$\rho_{a s}=2 \pi R\left\{\frac{1}{\frac{1}{(L-1)}-\frac{-1}{(L+l)}-\frac{1}{(L+l)}+\frac{1}{(L+l)}}\right\}$

$\rho_{a s}=\left\{\frac{2 \pi R \quad 1 / 4 L}{L^{2}-L^{2}}\right\}$

Note that $L^{2}-L^{2} \approx L^{2}$ since $L>>1$.

$\rho=\frac{2 \pi R L^{2}}{4 L}=\frac{\pi R L^{2}}{2 L}=\frac{\pi R(A B / 2)}{M N}$

$\frac{\rho_{a s}}{4}=\left(\frac{\pi R L^{2}-a^{2}}{a}\right)$

\subsection{Dipole - dipole configuration}

In this configuration, increased depth penetration is obtained by increasing the inter-dipole separation, the position of measurement is taken as mid-point of the electrode array (Figure 3). Where separation between their electrodes. The survey was carried out in September 2011.

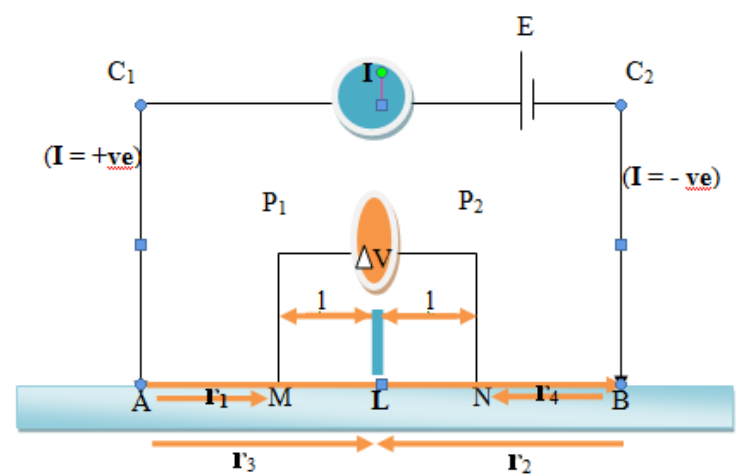

Fig. 3. Schlumberger array in resistivity survey

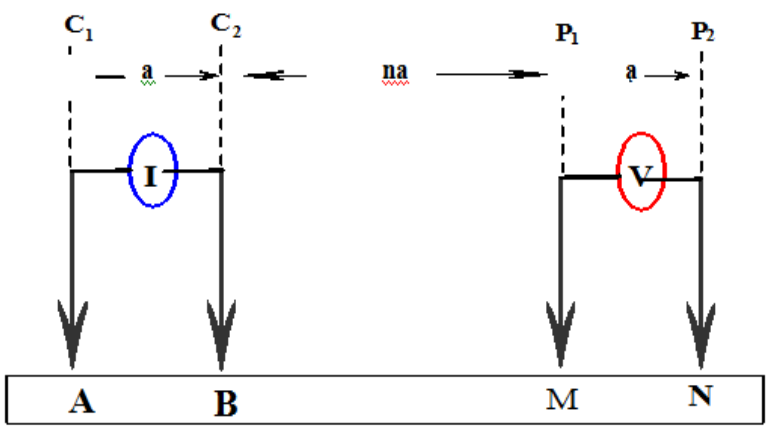

Fig.4. Dipole-Dipole array in resistivity survey

\subsection{Data acquisition}

A total of four vertical electrical sounding involving Schlumberger electrical array were carried out which were complimented with horizontal profiling method using the DIPOLE-DIPOLE electrical array. Throughout the surveys, electrode spacing of 5.0 was used. Earth's resistance was measured using the digital ABEM 1000 Terrameter while apparent resistivity was obtained by multiplying ground resistance with the geometric factor on a log$\log$ data sheet.

\subsection{Data presentation and processing}

The VES curves were obtained after being qualitatively interpreted through partial curve matching and computer iterations. The theoretical curves were generated to get thickness and resistivity values which were fed in to the WINRESIST software for computer iteration. The field curves were then compared to computer generated curves, where a good fit was achieved between the field and the computer curves, the interpreted results were considered satisfactory otherwise, the geoelectric parameters were modified and the procedure is repeated until a satisfactory fit is obtained.

\subsection{Procedure for partial curve matching}

Partial curve matching method involved the use of two-layer Master curves and the corresponding auxiliary curve. The interpretation technique involved the superposition of the field curve, on a set of two layer Master curve. The field curves were parallel to the corresponding axes of the Master curves at small electrode spacing. The origin (+) of the matched two - layer Master curve was marked on the field curve as $\mathrm{K}_{1}$.

The horizontal coordinate on the field curve gave the first layer resistivity $\left(\rho_{l}\right)$ while the vertical co-ordinate gave $\left(h_{1}\right)$ the first layer thickness. The reflection co-efficient $\left(\mathrm{K}_{1}\right)$ of the matched curve was noted. The curve which was then superimpose on the auxiliary curve while keeping the axes parallel and with (+) at the origin of the auxiliary curve, the appropriate auxiliary curve with the reflection coefficient $(\mathrm{K})$ was traced out on the field curve. The second layer's resistivity was determined from the relationship.

$\rho_{2}=\rho^{\left(1+k_{1}\right)} /\left(1-k_{1}\right)$

Where: $\rho_{1}$ - resistivity of the first layer;

$\rho_{2}$ - resistivity of the second layer;

$\mathrm{K}_{1}$ - resistivity reflection co-efficient at the interface between the first and the second layer.

This was then followed by matching the next segment of the field curve and the reflection $\mathrm{K}_{2}$ coefficient noted. The horizontal and vertical coordinates of the second cross point gave the replacement resistivity was obtained from the equation:

$\rho_{3 r}=\rho_{2 r}\left(1+K_{2} \mid 1-K_{2}\right)$

Where: $\rho_{3 r}$ - resistivity of the third layer;

$\rho_{3}$ - replacement resistivity of the second layer; 
$\mathrm{K}_{1}$ - reflection co-efficient between layers two and three.

To obtain the thickness $\left(\mathrm{h}_{2}\right)$ of the second layer, the first cross point was placed at the origin of the auxiliary curve with axis parallel. The Dn/Dr value was read off at the location of the second cross point $(+1)$. The second layer thickness was obtained from the relationship:

$h_{2}=\frac{D_{n}}{D_{r}}$ by:

The resistivity of the second layer was obtained

$\rho_{2}=\mathrm{k}_{1} \rho_{1}$

Therefore the general formula for the true resistivity of the nth layer is given below:

$\rho_{\mathrm{n}}=\rho_{(\mathrm{n}-1) \mathrm{r}} \times \mathrm{K}_{(\mathrm{n}-1)}$

Where: $\mathrm{n}$ is the number of layers. The thickness of the last layer was considered infinity. However the sum of the thickness from first layer gave the depth estimation to the resistive interface.

Dipole-Dipole results were interpreted using the DIPROFWIN (Dipro for Windows) computer software. The field data are multiplied with the ground geometric factor which was obtained using the formula:

$\mathrm{G}=\pi \alpha(n-1)(n-2) n$

Where: $\mathrm{G}$ - geometric factor;

$\pi-3.142$;

a - station spacing;

$\mathrm{n}$ - station number.

The resulting apparent resistivity data was fed in to the DIPROFWIN software to obtain pseudosections. Inversions were ran on the pseudosections to obtain a theoretical data pseudosections and a $2 \mathrm{D}$ resistivity structure of the subsurface.

\section{Results}

Table 1. Table showing Etioro-Akoko well inventories

\begin{tabular}{||l|l|l|l|l|l|l||}
\hline \hline Well No. & Longitude & Latitude & Elevation & Depth to water & Total depth & Water level \\
\hline 1 & $\mathrm{~N} 07^{\circ} 26.731$ & ${\mathrm{E} 005^{\circ} 43.200}^{\circ}$ & 1112 & 5.49 & 7.32 & 1.83 \\
\hline 2 & $\mathrm{~N} 07^{\circ} 26.274$ & $\mathrm{E}^{\circ} 05^{\circ} 43.383$ & 1054 & 4.08 & 5.18 & 1.1 \\
\hline 3 & $\mathrm{~N} 07^{\circ} 26.220$ & ${\mathrm{E} 005^{\circ} 43.409}^{\circ}$ & 1040 & 5.08 & 5.334 & 0.25 \\
\hline 4 & $\mathrm{~N} 07^{\circ} 26.593$ & $\mathrm{E}^{\circ} 05^{\circ} 43.250$ & 1108 & 6.09 & 6.49 & 0.40 \\
\hline 5 & $\mathrm{~N} 07^{\circ} 26.600$ & $\mathrm{E}^{\circ} 05^{\circ} 43.554$ & 1115 & 5.30 & 5.70 & 0.40 \\
\hline 6 & $\mathrm{~N} 07^{\circ} 26.596$ & $\mathrm{E}^{\circ} 05^{\circ} 43.310$ & 1111 & 5.53 & 5.73 & 0.20 \\
\hline 7 & $\mathrm{~N} 07^{\circ} 26.616$ & ${\mathrm{E} 005^{\circ} 43.532}^{\circ}$ & 1118 & 6.15 & 6.16 & 0.01 \\
\hline 8 & $\mathrm{~N} 07^{\circ} 26.610$ & $\mathrm{E} 05^{\circ} 43.251$ & 1111 & 6.2484 & 6.858 & 0.6096 \\
\hline
\end{tabular}

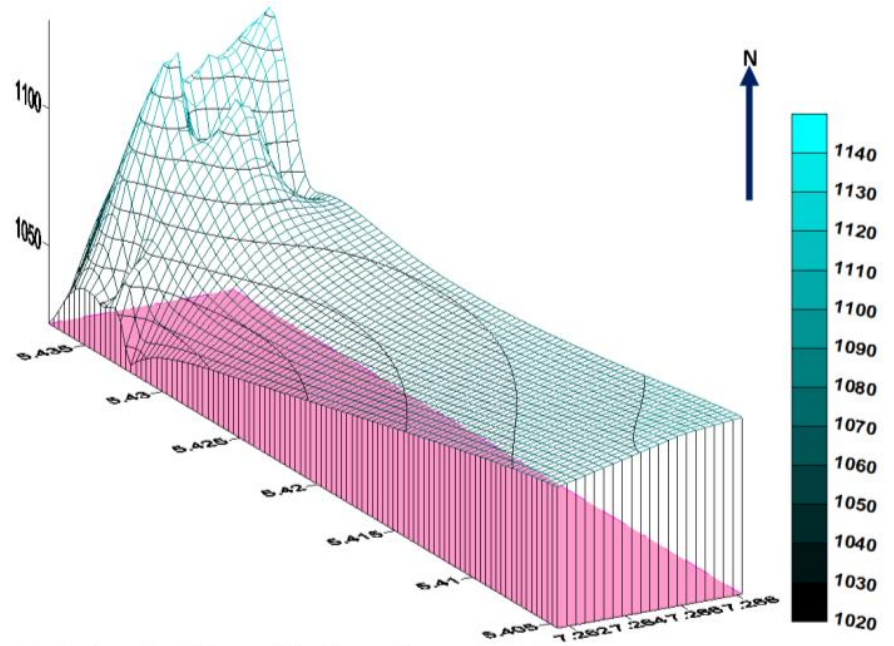

Fig. 5. 3-D wireframe map of Etioro -Akoko showing elevation of the study area

The topography map of the study area shows high elevation levels in some part of the town which neccesarily does not acccount for thick overburden cover in the subsurface. Etioro can be described to be on a hill, supported by the ascent and descent witnessed when entering or leaving the town.

A critical look at the topography map of Etioro indicates high elevation and topography at the Northeasterrn, North-western flanks of the town and a 
relatively flat topography towards the southern part of the town. Elevation peaks as high as $1140 \mathrm{~m}$ characterise the northern part of the town which is believed to be a recharge zone for the southern parts of the town.

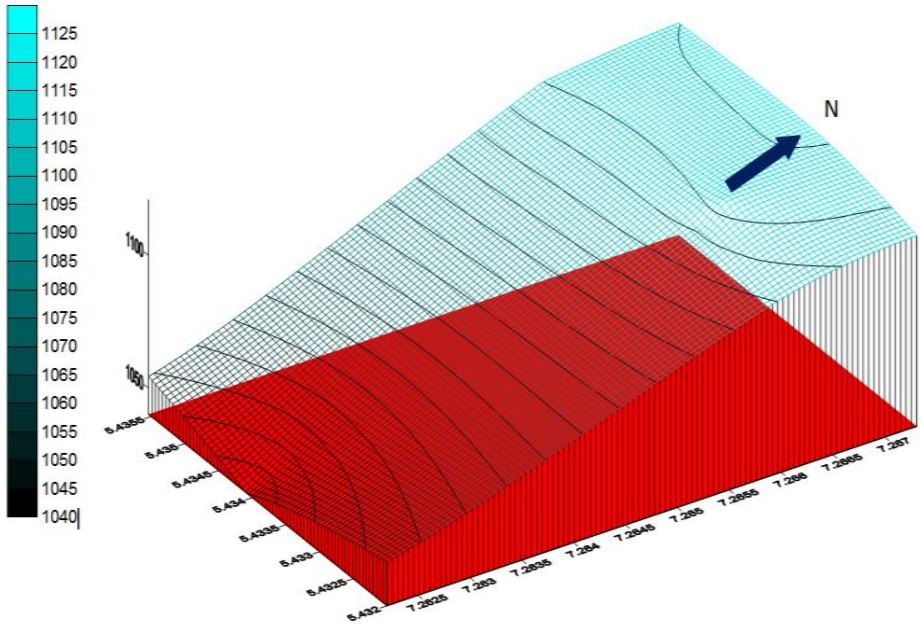

Fig. 6. 3-D wireframe map of well site elevations

The 3-D wireframe map of the well sites shows a topographical relief that slopes towards the southern part of the town. Field survey carried out at different times of the year however shows that productivity of wells in this area are seasonal. Productivity booms in the rainy season and reduces in the dry season. Wells situated in the southern part of the town are generally more productive than the ones located in the northern part. In theory, wells in Etioro are recharged by the precipitation, infiltration and run-off of rain water which accounts for seasonal productivity.

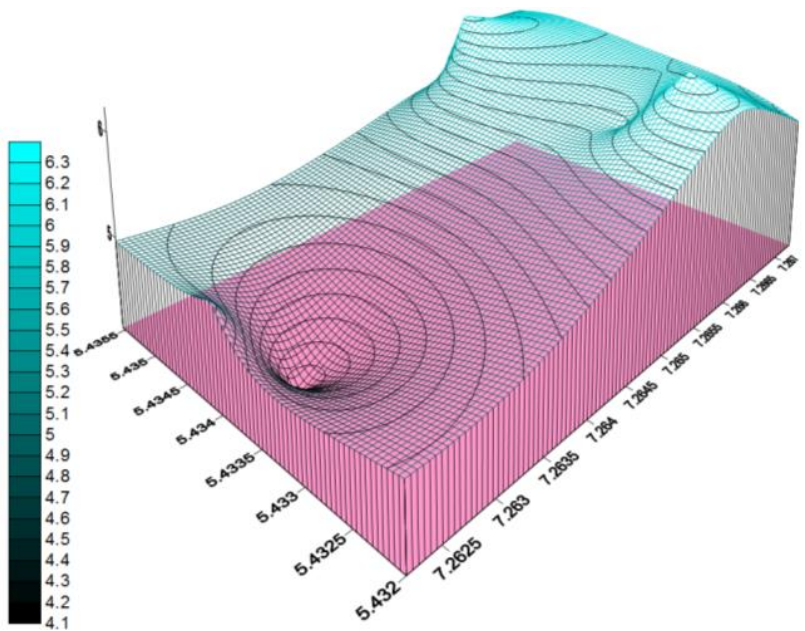

Fig. 7. 3-D wireframe map showing well depth to water

3-D map showing the depth of wells show lower depths for the seasonally more productive wells located in the southern part of Etioro town. Towards the southernmost part, where a deep depression is observed, there is a spring located around the area called Abata spring. This spring is a more reliable source of water than wells in the northernmost parts of the town. The axis of this spring also covers a depression witnessed throught out the study area characterised by a percieved descent while driving out of the study area Etioro towards Akungba.

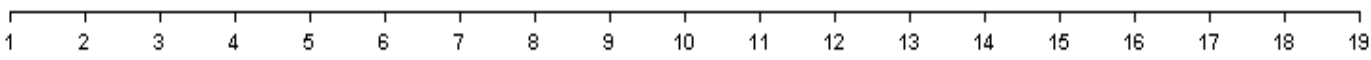

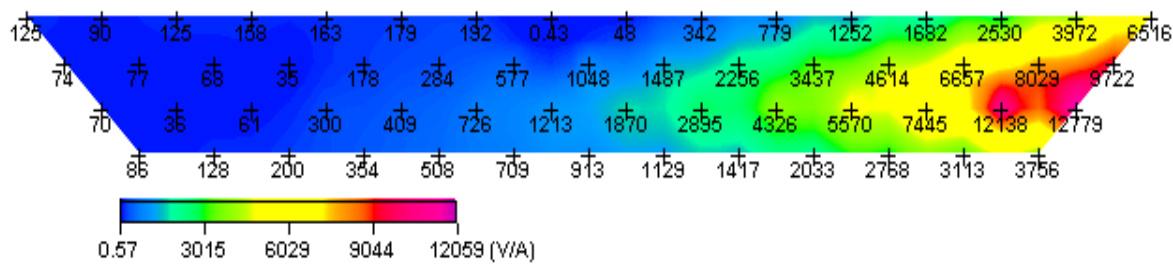

Fig. 8. (a) Dipole-dipole configuration showing Field data pseudosection 


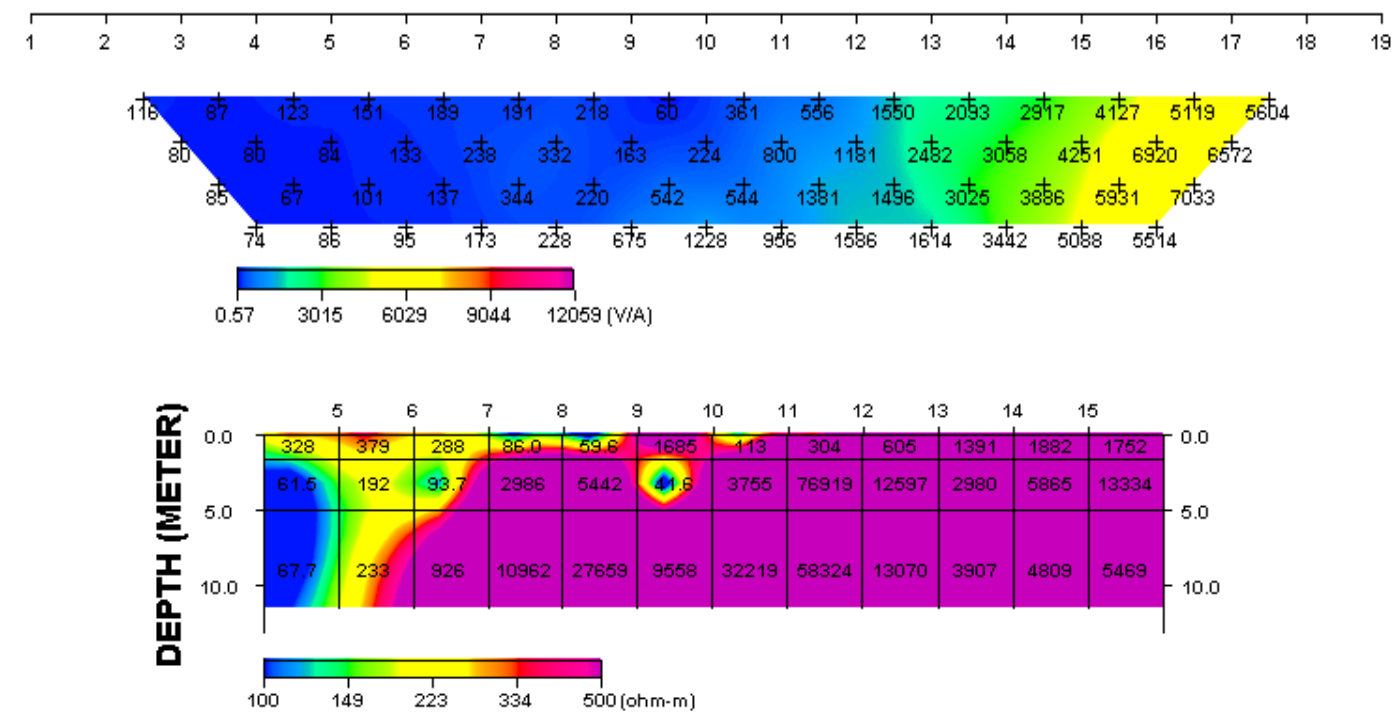

Fig. 9. (b) Theoretical data pseudosection and (c) inverted 2-D resistivity Structure

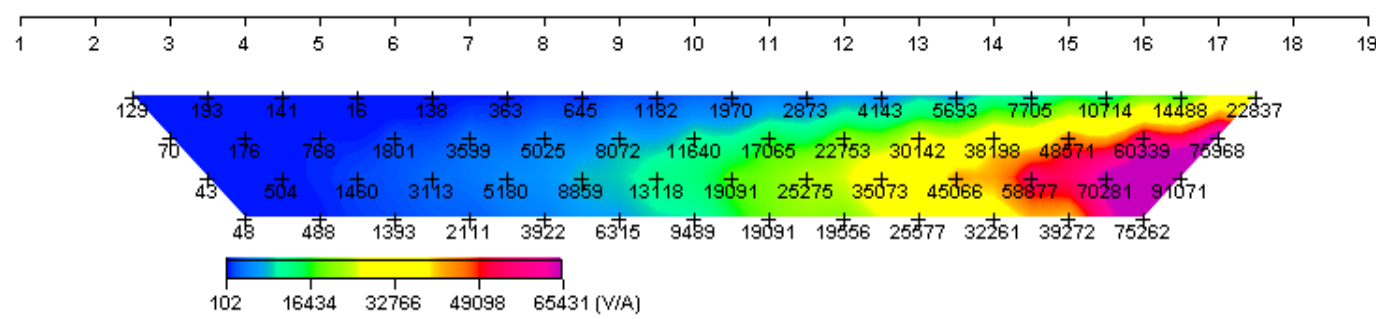

\begin{tabular}{lllllllllllllllllll}
\hline 1 & 2 & 3 & 4 & 1 & 1 & 1 & 1 & 1 & 10 & 11 & 12 & 13 & 14 & 15 & 16 & 17 & 18 & 19
\end{tabular}
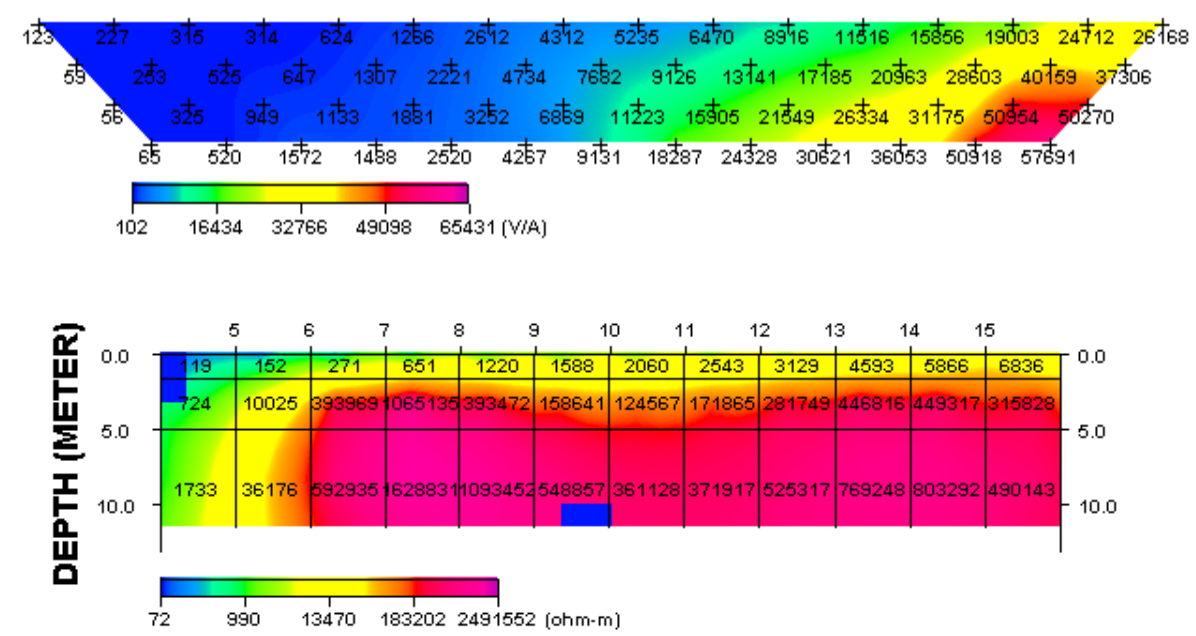

Fig. 10. (a) Dipole-dipole configuration showing Field ata pseudosection (b) Theoretical data pseudosection and (c) inverted 2-D resistivity structure

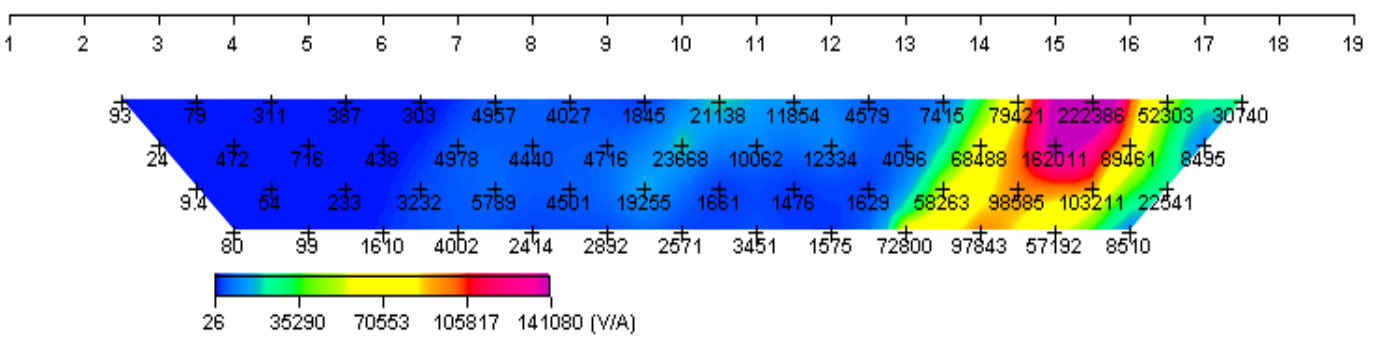

Fig. 11. (a) Dipole-dipole configuration showing Field data pseudosection 


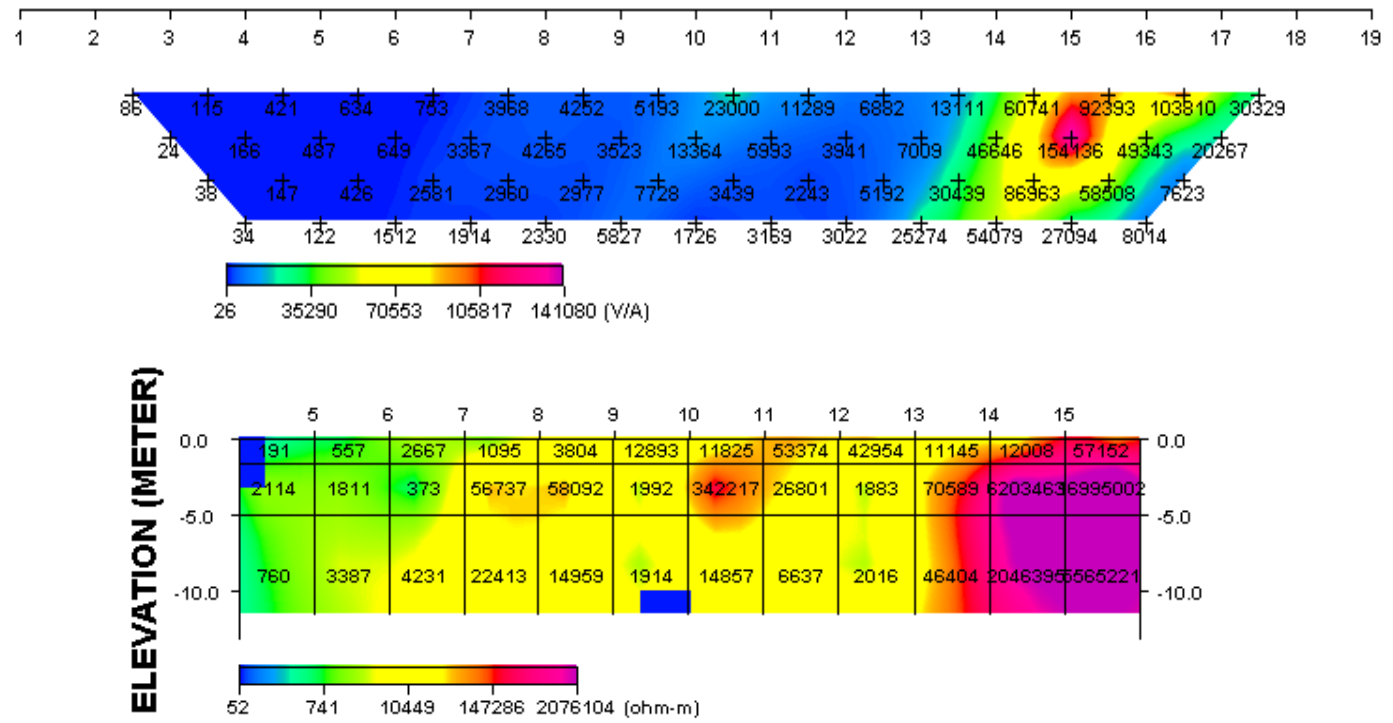

Fig.12. (b) Theoretical data pseudosection and (c) inverted 2-D resistivity structure

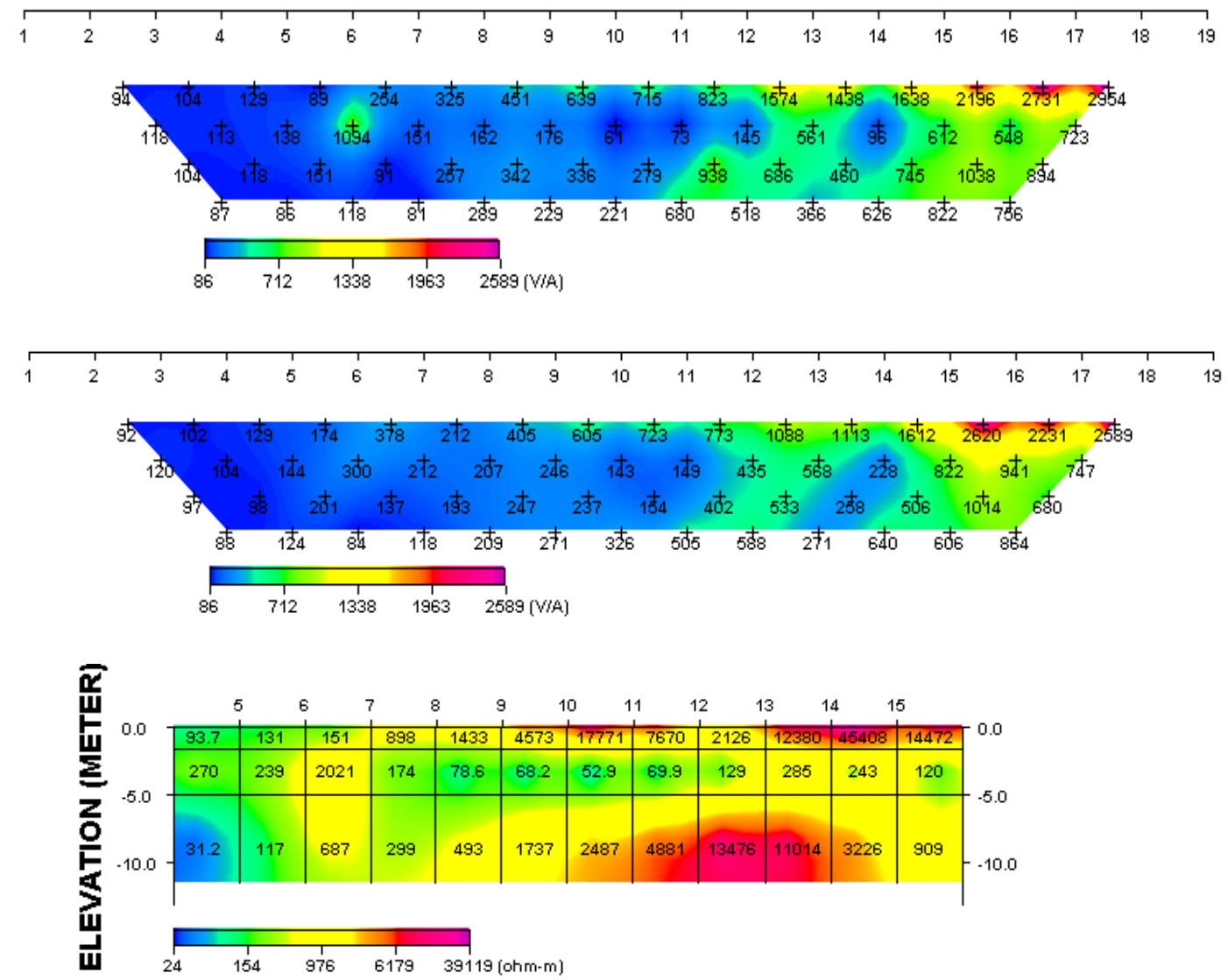

Fig.13. (a) Dipole-dipole configuration showing Field data pseudosection (b) Theoretical data pseudosection and (c) inverted 2-D resistivity structure

Table 2. Summary of the layer model interpretation for VES in the study area

\begin{tabular}{|c|c|c|c|c|c|}
\hline $\begin{array}{l}\text { VES } \\
\text { No }\end{array}$ & $\begin{array}{c}\text { Resistivity }(\omega-m) \\
\rho_{1} / \rho_{2} / \rho_{3} \ldots . p_{n}(o h m-m)\end{array}$ & $\begin{array}{c}\operatorname{Depth}(m) \\
d_{1} / d 2 / \ldots d_{n}(m)\end{array}$ & $\begin{array}{c}\text { Thickness(m) } \\
h_{1} / h_{2} / \ldots \ldots h_{n}(m)\end{array}$ & $\begin{array}{c}\text { Curve } \\
\text { type }\end{array}$ & "Hydrogeologic significance \\
\hline 1 & $1438.3 ` / 559.2 / 5709.2$ & $1.0 / 6.7$ & $1.0 / 7.7$ & $\mathrm{H}$ & Fairly good aquifer potential \\
\hline 2 & $433.5 / 502.3 / 3588.7$ & $1.1 / 5.6$ & $1.1 / 4.5$ & $\mathrm{H}$ & Poor aquifer potential \\
\hline 3 & $607.4 / 196.4 / 2598.3$ & $0.6 / 6.8$ & $0.6 / 6.2$ & $\mathrm{H}$ & Fairly good aquifer potential \\
\hline 4 & $403.5 / 201.0 / 3466.6$ & $1.1 / 5.6$ & $1.1 / 4.5$ & $\mathrm{H}$ & Poor aquifer potential \\
\hline
\end{tabular}




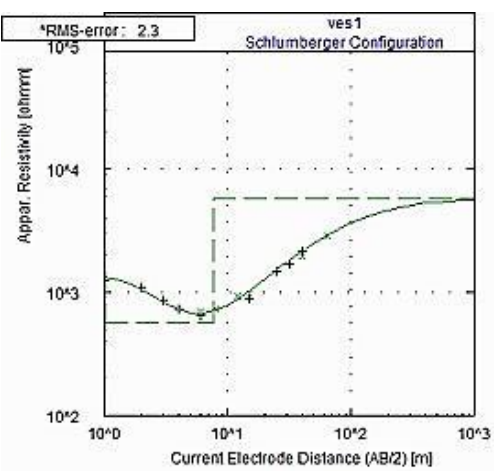

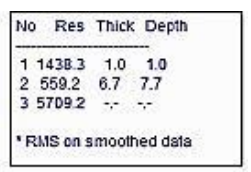

(a)
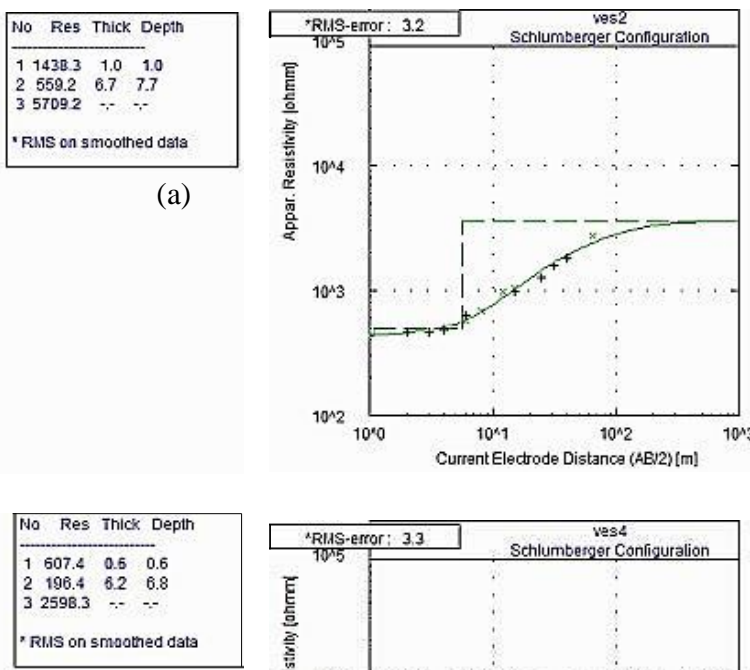

(c)

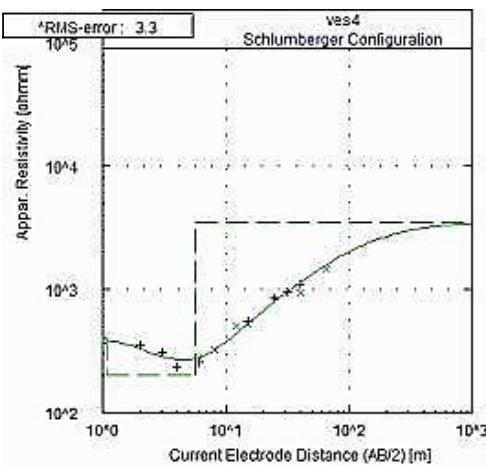

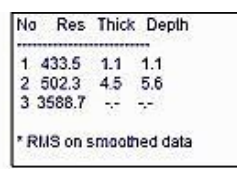

(b)

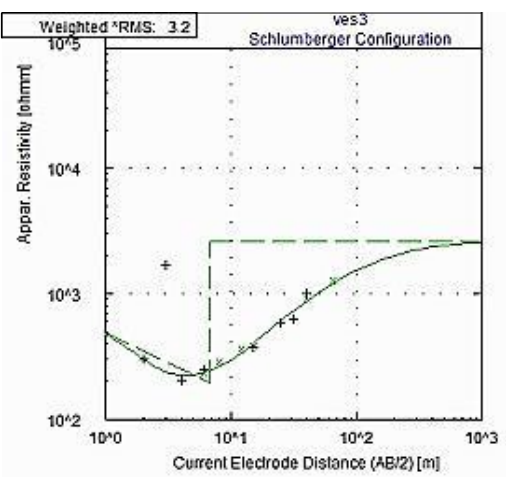

Fig. 14. Picture (a-d) showing characteristics VES $(H)$ curve of the study area

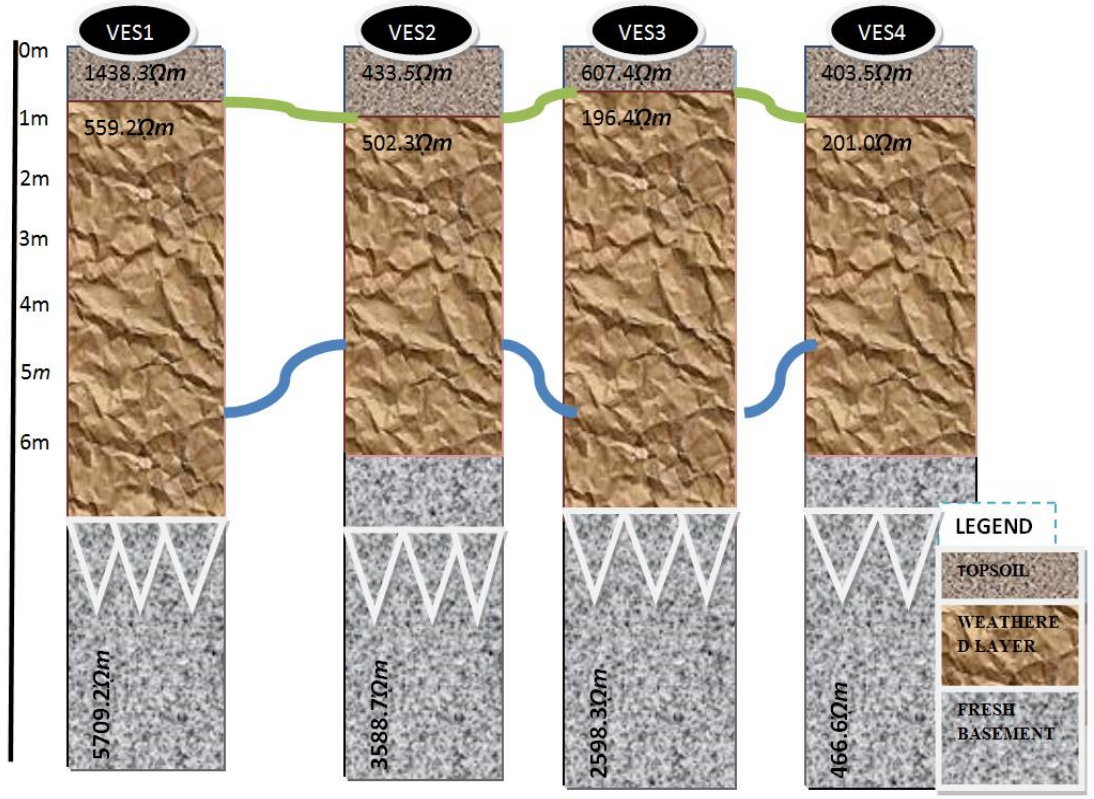

Fig. 15. Lithology and aquifers borehole log

The four VES curves obtained were plotted as a lithology and aquifers borehole log (Figure 15). The lithology and aquifers borehole log displays three distinct geologic layers which are the top-layer, the weathered layer or the partly weathered layer and the fresh basement rocks.

The Topsoil. The topsoil resistivity values vary from 403.5 to $607.4 \Omega m$, and the thickness values range from 0.6 to 1.1 meters.

The Weathered/Fractured Layer. This layer should bear the main aquifer units if it has appreciable thickness. It has resistivity values ranging from196.4 to $559.2 \mathrm{Qm}$ and a thickness in the range of 4.5 to $6.7 \mathrm{~m}$.
The Fresh Basement. This is the last obtainable layer with resistivity values ranging from 466.6 to $5709.2 \Omega m$ and thickness value that tends towards infinity.

\subsection{Pseudosection interpretation}

Results have been interpreted using the field data pseudosection, theoretical data pseudosection and 2-D resistivity structures. The features in terms of resistivity and conductivity are hereby discussed.

Inverted resistivity pseudosection shows the distribution of resistive and conductive materials across the area of study. Predominantly resistive 
structures are intersected by, or witness pockets and flanks of conductive materials. In most cases, the depths of penetration of these conductive materials are not enough to support productivity of groundwater.

The 2-dimensional resistivity structure in the first traverse of dipole-dipole array carried out shows a high resistivity pseudosection with arms and pocket of low to middle resistivity. This conductive flank extending from the first station through tp the fourth station is highly penetrative and supplies a pocket of high conductivity towards the fifth station. Groundwater potential in this zone is feasible barring any contamination.

In the second traverse of the dipole-dipole pseudosection, a thin conductive layer of approximate thickness 1 meter generally overlies a highly resistive structure. There is a flank of penetrative conductive structure suggesting a fracture with the thin layer of overlying structure indicative of weathered materials or clay.

The third traverse of dipole-dipole pseudosection is characterized by a trend of increasing resistivity across the 2-D resistivity data. Towards station 13-15 marks a zone of very high resistivity and low conductivity, with a penetrative resistivity form. The resistivity decreases towards the beginning of the traverse. This information, when matched with the topography, location and slope of this area can be said to be of better groundwater productivity. This location is close to a stream and wells in this location are fairly productive during the rainy season of the year.

The fourth traverse is a dominantly conductive area; indicative of a weathered region however, there is a zone of very high resistivity at the station 1 towards station 3 starting at a relative depth of 5 meters. Low conductivity and high resistivity is present as a topsoil layer starting from station 9 to the end of the traverse, with a shallow depth of less than 2 meters. This structure may suggest either a highly compacted region or the presence of a large boulder body. A structure of similar resistivity is present just beneath this shallow layer which is more penetrative starting from a depth of more than 5meters and extends beyond the depth of the traverse.

\section{Conclusion}

Well inventory results of Etioro-Akoko shows thin overburden layer comprising of both the topsoil and weathered layer ranging from 5.3meters to 7.3 meters found at different points and locations in the study area. Thin overburden layer has been proven to have low groundwater yield and also provides evidence that groundwater recharge in this area is principally from precipitation and infiltration. This is probably responsible for the dryness witnessed during the dry seasons.

Four VES stations were investigated, interpreted and presented in form of 2 dimensional geoelectric sections shows a system of three geolectric layers in the topsoil, weathered layer, and the fresh basement.
The depth to basement which is the major parameter needed shows thin layer of overburden ranging from 4.5 to 7.7 meter, evidence corroborated by the results of well inventory in the study area. Therefore drilling of boreholes in the study site might be a futile exercise because of the thin overburden thickness.

3 dimensional maps showing well point elevation, well depth and overburden thicknesses reveal a recharge and discharge pattern which runs southwards in the study area. Recharge from the northern part of Etioro is discharged at the southern part where there are thinner depths to well base. Groundwater flow pattern of the study area can be constructed using these maps as guide.

Dipole-dipole results as presented in pseudo sections provide evidence of non-penetrative structures like fractures and pockets of weathered layers. As a result of the thin overburden layer, the depth of investigation is limited to above 10 meters. However, conductive structural patterns which are indicative of high groundwater yield potential are not abundant in the area of study, thereby limiting the rate of productivity of wells situated in Etioro.

\section{References}

Adegoke Anthony C.W. and Ajayi O. (1988). Groundwater Prospects in the Basement Complex Rocks of SouthWestern Nigeria. Journal of African Earth Sciences, Vol. 7 No. 1 PP 227-235.

Ayodele J.O. (1988). Tropical hydrology and water resources. Journal of African Earth Sciences, Vol. 7 No. 1 Pp 201-202.

Hamil, L. and Bell, F.G. (1986). Groundwater Resources Development, Britain library cataloguing in Publication Data, London,Pp 151-158.

Ojo S.O. (2000) Factor productivity in maize production in Ondo state Nigeria. Applied Tropical Agriculture, pp 23, 25-26.

Olayinka A.I. and Olorunfemi M.O. (1992). Determination of Geoelectric characteristics in okene area and implications for borehole sitting, Journal of Mining and geology, Pp 403-411.

Olorunfemi M.O. (1990). The Hydrogeological Implication of Topographic Variation with Overburden Thickness in Basement Complex Area of Southwestern Nigeria, Journal of Mining and Geology, Vol26, No 1.

Olorunfemi M.O. and Oloruniwo M.A. (1985). Geoelectric Parameters and aquifer characteristics of some parts of southwestern Nigeria, Geologic Applicate, E. Hydrogeologic Pp 99-109.

Omosuyi G.O., Ojo J.S., Enikanselu P.I. (2003). Geoelectric Sounding to Delineate Shallow Aquifer in Obanla, Obakekere Area of Akure, Ondo state. Journal of Mining and Geology, Vol26, No 1. pp 26-27. 


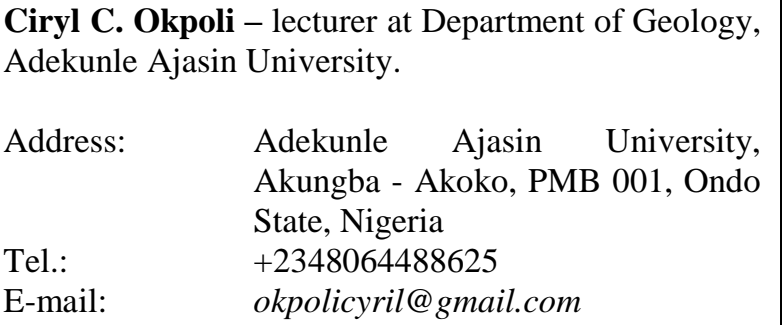

Emmanuel A. Saba - lecturer at Department of Geology, Adekunle Ajasin University.

Address: Department of Geology, Adekunle Ajasin University, Akungba Akoko, Ondo State, Nigeria

E-mail: sabaayodeji@yahoo.com

Christopher O. Oduneye - lecturer at Department of Earth Sciences, Ladoke Akintola University.

Address: Department of Earth Sciences, Ladoke Akintola University, Ogbomoso, Oyo State, Nigeria

E-mail: chrisodus01@yahoo.com

\title{
Geofizinis požeminio vandens valdymo tyrimas. Etorio-Akokas Nigerijos pietvakarių atvejo analizé
}

\author{
Okpoli C. Cyril ${ }^{1}$, Saba A. Emmanuel ${ }^{1}$, Oduneye O. Christopher ${ }^{2}$ \\ ${ }^{I}$ Geologijos fakultetas, Adekunle Ajasin Universitetas, Akungba - Akokas, Ondo valstija, Nigerija \\ ${ }^{2}$ Gamtos mokslu fakultetas, Ladoke Akintola Universitetas, Ogbomosas, Oyo valstija, Nigerija
}

(gauta 2013 m. rugsèjo mèn., priimtas spaudai 2014 m. rugsëjo mèn.)

\begin{abstract}
Elektros varžos tyrimai Etioro-Akoke yra svarbi tyrimų sfera dẻl ypač pablogejjusių geriamojo vandens funkcinių savybiu šiose apylinkėse. Pagrindinis tyrimo tikslas yra nustatyti geologinę sąranką per hidrofizinius metodus ir šulinių modeliavimą. Šioje studijoje šachtiniams šuliniams buvo nustatyti „dipolisdipolis“, Šlumbergerio ir „rankos padèties“ vektoriai.

„Dipolis-dipolis“ vektoriaus rezultatai neparodè aukšto požeminio vandens takumo potencialo indikacijų. Buvo aprašyti trys sluoksniai (paviršinis, eroduojantis ir šviežio pagrindo) naudojant Šlumbergerio vektorių, kai sluoksnio storis 4.5-7.7 m (padidintas). Reikšmès yra per mažos, kad atitiktų produktyvius šulinius. Šulinių parametrų (gylis iki šulinio pagrindo) rezultatai buvo nuo 5.3-7.3 m, jie panaudoti modeliuojant požeminio vandens srovès krypties šabloną. Piečiausia dalis žemėlapyje yra tolygiai nevandeninga. Norint nustatyti požeminio vandens išteklius šiose srityse būtina sudaryti išsamius geofizinius žemėlapius bei atlikti detalesnius tyrimus.
\end{abstract}

